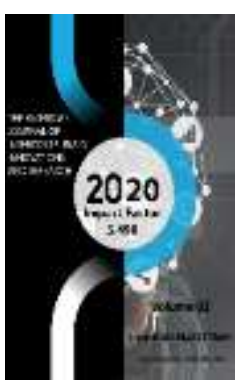

\title{
Political and Dynastic Relations Of Kievan Rus
}

\author{
F. Khudaynazarov \\ Researcher, International scientific research center of Imam Termizi, Uzbekistan
}

Journal Website: http://usajournalshub.c om/index,php/tajiir

Copyright: Original content from this work may be used under the terms of the creative commons attributes 4.0 licence.

\section{ABSTRACT}

This article discusses the main political ties formed as a result of dynastic marriages in Kievan Rus. This trend is of great importance in Russian history, as dynastic marriages were the basis of the political structure of the Russian state during the Kievan Rus.

\section{KEYWORDS}

History, dynastic marriages, Kievan Rus.

\section{INTRODUCTION}

As a result of the long internal formation of the Slavic tribes, a strong state - Kievan Rus was established. In the 9th century it was considered one of the largest states in Europe. The middle Dnieper region became the center of Russia, since it was here that signs of socialization arose. Many Byzantine authors considered the first Slavic community to be Rus. The people who were part of this association were called Russians. Kievan Rus began to be called because it has long been considered the capital of the state. The role of Kievan Rus in the history of the Eastern Slavs is enormous. The Slavic tribes gradually formed the ancient Russian nation, which was associated with the formation of ethnic unity against the background of the unification of the whole state. Statehood was based on territorial unity, linguistic unity, a single culture, and so on. Ethnic unity was based on Russian, Ukrainian, and Belarusian peoples. The people of Ancient Rus were formed through further consolidation. Also, the formation of a single 
state has significantly improved the economy, politics and culture of the Slavic people. The culture created by the ancient Russian people withstood all the temporary difficulties. The formation of Kievan Rus was of great importance to other peoples who did not belong to the Slavs. All the assets of Kievan Rus were actively used by other peoples. Some of these peoples were ethnically and politically united within the Old Russian state. Ancient Russia had an important place in the world. This basic position was related to economic, political and cultural relations with many eastern and western states [1].

\section{Development of the Trade Route "From the Varangians to the Greeks" The Content and Meaning of the Russian-Byzantine Treaties of Oleg and Igor}

In the 9th century, a center was established in Novgorod under the leadership of Rurik. The main direction of the policy was to establish new ties with the southern states. This was due to the great interest in the Black Sea. Traders in the southern regions brought a variety of goods from there. According to the description of the travelers, the main focus was on the great Constantinople [3].

In 866 there were attempts by Askold and Dir to march to Constantinople, but they were unsuccessful. A year later, Patriarch Photius managed to establish a diocese there that converted to Christianity [2].

In 882, Prince Oleg again undertook a campaign to the south along the Dnieper. The mission was no longer of an intelligence nature, but as an establishment of contact with the people who live along the Dnieper. The Dnieper was considered a very attractive trade route, and very profitable in the captivity of the control of trade between the southern and northern territories.
Of particular interest is the campaign of Prince Oleg, which was in 907. According to The Tale of Bygone Years, this was a combined raid across Bulgaria. The raid combined the cavalry and sea routes. Several thousand boats took part in the latter. Thanks to such a move, Constantinople was attacked both from land and sea. However, its outskirts were brutally plundered and destroyed.

The inner part of the city was defended by the Greeks, but Oleg was still able to break through the city's defenses and burst inside. The Greeks asked for peace. Later they agreed to pay tribute and conclude a trade union, the terms of which were certainly beneficial for the Russians. Before leaving the city, according to legend, Oleg hung his shield on the city gate [5].

The authenticity of this campaign is still debated among modern historians. The only proof of the truth is the content of the treaties with Byzantium concluded in 907 and 911. The first agreement in the "Tale of Bygone Years" was briefly mentioned, and the second agreement is presented in full, which proves its veracity and which were signed only for the reason that Byzantium suffered a military defeat [4].

This agreement assumed that the Russians would have certain privileges. There are also payments of 12 hryvnia for each soldier and tribute to the mayors of the cities under Oleg's control. Also, Byzantium was obliged to provide products and goods to merchants who stayed in the city. Russian merchants had the right to visit the city (without weapons and accompanied by a city official) [7].

The 907 treaty was supplemented by a number of amendments in 911. The legal framework for relations between Greeks and Russians was determined. This was appropriate for the 
regulation of contentious situations. The responsibility of both parties arose for the crimes committed. Also, agreements in the field of military affairs were concluded between Constantinople and Kiev. There is a known fact that in 911, Russian soldiers were part of the Byzantine soldiers in the campaign against the Arabs [8].

The conclusion of a peace treaty between Kievan Rus and Byzantium is of historical importance. This treaty shows Russia as a young and strong state.

Russia was also attracted by the countries of the Arab Caliphate. They are located on the southwestern coast of the Caspian Sea. In the annals of Arab writers, evidence was found of campaigns in these states.

Oleg's success in the southern territories opened a very profitable trade route for the Russian state.

After Oleg's death in 912, Igor (912 - 915) became prince. There are discrepancies in the letters about Igor's reign and Oleg's death. The very personality of Igor is very contradictory and mysterious. The connection between Igor and Rurik is highlighted only in the only chronicle about the capture of Kiev by Oleg [9].

During the reign of Igor, the biscuits approached the southern borders of the state. But in 915 a peace treaty was made with them and they returned to the Danube. Peace lasted until 920 years. It is not entirely clear who was the first to violate the terms of the peace treaty, but there are records that the Byzantine side was to blame for this. With the threat of the Pechenegs, Byzantium tried to put pressure on Russia. In Kiev, this was not immediately noticed and continued to provide military assistance to the imperial court [10].
In 941, relations between Russia and Byzantium collapsed. Igor used martial law between Constantinople and the Arabs, and attacked Byzantium. However, Igor was defeated. In 943 the Russians made a number of successful campaigns. One of which goes east to the cities of Berdaa and Derbent. Warriors returned home with good booty [11].

In 944, another campaign was launched against Byzantium in retaliation for the campaign. But the emperor was warned and sent ambassadors to make peace. A new peace treaty was signed, but it was less beneficial for Kievan Rus. Now the merchants had to pay the Byzantine tax. Igor was obliged to defend the Byzantine lands from the Bulgarian troops from the Crimea. This agreement is considered a very important achievement of Igor in politics [13].

\section{Christianization of Rus and its Consequences: Strengthening the International Positions of Rus.}

The ninth century is one of the most interesting in history. The most remarkable event in which he distinguished himself is the formation of Kievan Rus in the East of Europe. The young power gradually strengthened and after a while its position was getting better. Over time, both trade and relations with the surrounding peoples developed. But, not everything is so smooth. All major states of the north were not in any business with Russia. The reason for this was their paganism [15].

Time passed, but the position of Russia did not get better, and over time paganism began to hinder the development of medieval statehood. This type of statehood was characterized by the fulfillment of strict requirements of the feudal type, the centralization of the institutions of society, 
where a single ruler stood at the head of everything.

To answer the question: why did paganism hinder development? You need to know its features. The peculiarities of paganism were the interpretation of the freedom-loving people, who made speeches against the government. A person who was a pagan could encroach on personal freedom. In addition, because of paganism, trade with countries professing other cultures, usually Christianity and Islam began to suffer more severely. All this did not fit the principle of strict control of the feudal type, and therefore, the adoption of another religion was an urgent need. Only in this way it was possible, at least partially, to equate Russia with other states.

A peculiarity of paganism was that people who relied on this faith entered into a certain agreement with the gods who were responsible for one or another force of nature. However, the resulting inequality in society did not give the right to life for this religion. Feudalism began to strengthen with every year. All this influenced the current traditions of some groups of free communes. Along with the loss of this role came another - ancient traditions no longer connect different groups of the population. In this regard, other contradictions arose, but one way or another, this religion did not allow society to develop, and therefore it had to be replaced.

Against the background of the development of society, a new stratum of society appeared these are the people who owned land. They were unhappy with the current situation when a person, relying on his faith, wanted to preserve everything for subsequent existence after death. This layer needed to get a certain surplus product. This was one of the conditions for the development of feudal relations. The situation worsened, and therefore required urgent action. To begin with, Prince Vladimir in the 980 s carried out a reform that was supposed to change the situation, however, this did not happen and the people did not accept the imposed images of the gods [16].

The penetration of Christianity in Russia took place at the beginning of the gth century. Then they started talking about the Apostle Andrew as a mission. As you know, at that time there was a struggle between Russia and Byzantium for possessions in the Crimea, in the 12th century. Thus, the author who brought this information to us wanted to show that Russia owes its baptism only to Vladimir, and not to Byzantium.

However, we have no evidence that Christianity also penetrated in the middle of the first millennium AD. And we also cannot say about the Christianization of Bravlin, the prince of Novgorod. Although this prince could undergo Christianization only during the campaign against Suroj in the late 8th, early 9th century [20].

The very first Russian Christians were merchants. All this is not casual. Merchants did business with other nations, and therefore, the adoption of Christianity helped them to carry out transactions and also made them a discount, and the discount consisted of $50 \%$ of the cost of the goods.

They tried to baptize Russia several times. The first attempt was made in 866 . This attempt was unsuccessful, and they decided to do so in view of the anti-Byzantine campaign and the outbreak of the disease. The bishop's work was also affected, but as mentioned above, it all failed. They then tried to baptize Russia again in the period from 872 to 877 . This baptism also affected the gladeus in Kiev [17]. 
In 882, a new prince appeared at Kiev - Oleg. In the same year, it was decided to unite Novgorod with Kiev. At that time, there were also constant conflicts between Byzantium and Russia. All this caused certain disturbances in society, and so people did not want to accept the Byzantine religion. At the same time, the role of the Christian community in Kiev grew, and over time began to influence the government. However, these are not the only reasons for the spread of Christianity. Oleg's argument with the priests played an important role. The subsequent warming of relations with Byzantium increased the influence of Christianity on Russia. After that, in the 10th century, the union of Russia and paganism fell apart.

When Igor began to rule, the number of Christians began to grow. Moreover, its influence began to occur in all spheres of society. Thus, he entered a vicious circle, as well as the princedom, drujina, and so on.

But, undoubtedly, over time various, unrest began to arise within the people, and therefore, at a certain point, this led to a conflict. This conflict arose at the time of Olga's reign. When Olga's husband died, she decided to seek help from the Kiev Christian community. Olga, having made a decision, went to Constantinople in 944 and adopted Christianity of the Byzantine type. Thus, she was able to improve relations with Byzantium and received some kind of power. The Kievans also gave her their support, and therefore she removed her son from the throne and suppressed the uprising of the Drevlyans. But, this does not end there, and Olga then decides to go back to Byzantium in order to strengthen the alliance with Constantine Porphyrogenitus, who was the new emperor [21].

A pagan political society appeared in Russia and was headed by Svyatoslav. Parallel to this, a Christian political group, headed by Olga, also arises. The second is to spread Christianity and build a church. Christianity is still part of the military, despite Svyatoslav's denial.

But Olga's attempts to baptize Russia will not be crowned with success. Svyatoslav completely prevents this. And Olga turns to the west for help, but Western Catholics, having arrived in Russia, met negative and rushed to leave the state. Olga, having lost allies, finally transferred power to Svyatoslav and his "paganism".

Svyatoslav was almost not interested in the internal problem of Russia. He felt like a warrior who had to conquer distant territories. Svyatoslav conquered many Khazar lands and strengthened the position of Russia in the south. After the war with Byzantium, Russia came under control of Bulgaria.

Christianity in Russia was going through hard times. Many adherents of the religion were denied many of the privileges that the pagans had. During the reign of Svyatoslav, the church of Nicholas was destroyed.

The prince died at the hands of the Pechenegs, and most likely the Russian Christians had something to do with this.

After the accession to the throne of Svyatoslav's son, Yaropolk, Christianity was again strengthened in the state. This did not quite please the pagans. A rivalry arises between Christians and pagans.

The pagan society is headed by Vladimir. An important part of the content goes to him. Soon Vladimir fires Yaropolk. The other dies at the hands of his detachment. Christianity was defeated in 979 [22].

However, pagan religion failed to achieve its goals for the state. In 980, there were attempts 
by Vladimir to implement a series of reforms to improve the political situation. Relations with Christian countries have become increasingly complicated. As a result, all reforms failed.

In 988, Kievan concluded a treaty of mutual aid between the Russian and Byzantine empires, which, according to the custom of the time, was to be made in conjunction with Vladimir's dynastic marriage to the Byzantine queen Anna. The Kiev Imperial Court helped suppress the revolt of Bardus Focas, who was on the verge of collapsing due to many unfavorable domestic political factors. Probably that year Vladimir was secretly baptized.

Nevertheless, the Byzantine emperors did not fulfill their part of the treaty - they did not give either Princess Anne or an autonomous church organization to the Prince of the Rus. In response to this deceit, Vladimir laid siege to the center of the Byzantine Crimea, the city of Chersonesos (Korsun), and captured it in the spring of 990. Byzantium was forced to concede and fulfill its part of the treaty. The wedding of Vladimir and Anna probably took place in Chersonesos. In the summer of the same year, the Byzantine clergy, accompanied by the princely army, arrived in Kiev.

The city was baptized in several stages during the summer of 990. Even in Korsun, the prince's detachment underwent Christianization. The Kiev nobility, humbled by that time by the princely power and the army, also received baptism. Vladimir ordered the destruction of statues of pagan gods throughout the city, which served as a kind of psychological preparation of the townspeople to accept the new faith [18].

On July 31, a new decree was issued: the entire population of Kiev should come to the banks of the Pochayna River the next day. On August 1, 990, an official mass baptism took place in
Kiev. Not all citizens obeyed the order - many pagans left the city and hid in the "forests and deserts."

In general, thanks to the adoption of Christianity, Kievan Rus was included in the European Christian world, and therefore became an equal element of the European civilization process. However, the adoption of Christianity also had negative consequences. Orthodoxy contributed to the isolation of Russia from Western European civilization. With the fall of Byzantium, the Russian state and the Russian Orthodox Church found themselves, in fact, isolated from the rest of the Christian world. It is this circumstance that can partly explain the refusal of Western Europe to come to the aid of Russia in its confrontation with the infidels (Tatar-Mongols, Turks and other conquerors) [19].

Search for new ways to strengthen the international positions of Russia. Dynastic marriages of the ruling dynasty

Dynasty marriages were rare in Kievan Rus. Vladimir also sent his wax to save the Byzantine Empire from revolts, in exchange for the hand of his sister Basil and Constantine (Byzantine emperors). The Kiev prince was well aware that he had a rare chance to intermarry with the rulers of Byzantium. But still the greatest development was received by the three dynastic marriages of the three daughters of Yaroslav the Wise. Each of these three marriages obviously had a political side.

The marriage of Harald Sigurdarson and Elizabeth Yaroslavna strengthened RussianNorwegian ties, which were friendly during the time of Olav Haraldsson - at least since 1022, that is, after the death of Olav Shotkönung, Jaroslav's father-in-law, and the assumptions of power in Sweden by Enund-Jakob, who soon entered into an alliance with Olav Haraldsson 
against the Great Cnut - and during the time of Great Magnus (1035-1047), who was enthroned to the Norwegian throne not without the participation of Yaroslav the Wise [16].

The matchmaking and wedding of Anna Yaroslavna took place in 1050, when she was 18 years old.

Already at the beginning of her royal journey, Anna Yaroslavna accomplished a civil feat: she persisted and, refusing to swear allegiance to the Latin Bible, took an oath on the Slavic Gospel, which she brought with her. Under the influence of circumstances, Anna then converted to Catholicism. Arriving in Paris, Anna Yaroslavna did not consider it a beautiful city. Although at that time Paris from the modest residence of the Carolingian kings turned into the main city of the country and received the status of the capital. In letters to her father, Anna Yaroslavna wrote that Paris was gloomy and ugly she complained that she was in a village where there were no palaces and cathedrals, which Kiev was rich in.

Anna's life in France coincided with the country's economic recovery. During the reign of Henry I, the old cities were revived: Bordeaux, Toulouse, Lyon, Marseille and Rouen. The process of separating trade from agriculture is accelerating. Cities began to liberate themselves from the power of lords, that is, from feudal dependence. This led to the development of commodity-money relations: city taxes bring income to the state, which contributes to the further strengthening of the state. Anna Yaroslavna was widowed at the age of 28 .

Very little is known about the historical literature of the last years of Anna Yaroslavna's life; so all the available information is interesting. Anna was waiting for news from home. The news came in a different way - sometimes bad, then good. Soon after his departure from Kiev, his mother died. Four years after the death of his wife, at the age of 78, Anna's father, Grand Duke Yaroslav, died. The disease broke Anna. She died in 1082 at the age of 50 [13].

The personality of Anastasia (preserving prudent skepticism, we will not completely rely on the rather late author) Yaroslavna was better imprinted in the Hungarian tradition; cf., for example, a passage from Acts of the Hungarians Anonymous, not devoid of some lyricism: Andrey often spent time in the castle Komarom "for two reasons: firstly, it was convenient for royal hunting, and secondly, his wife loved to live in those places, because they were closer to [her] homeland - and she was a daughter Russian prince and was afraid that the German emperor would appear to avenge the blood of [King] Peter".

Leaving on the conscience of "Anonymous" his weakness in geography (Komarom was on the Danube, near the mouth of the Vag River, that is, noticeably closer to the German border than to the Russian one), let us note the game of fate: when, by the end of Andrey's reign, the one radical change and Andrei was overthrown by the brother of White I (1060-1063), Anastasia with her son Shalmon, married to the sister of the German king Henry IV (1056-1106), found refuge in Germany. And the entire period of Shalamon's reign (1063-1074, died about 1087), he had to defend the throne in the struggle against the sons of Bela - Geza and Laszlo, who were looking for support, including in Russia (they were the nephews of Gertrude, the wife of the Kiev prince Izyaslav Yaroslavich). Anastasia, according to legend, died in the German monastery of Admont, not far from the Hungarian-German border.

You can clarify the political position of Vsevolod, taking into account the marriage of 
his son Vladimir Monomakh, which was concluded in the same way as we study. Vladimir Vsevolodovich married Gide, the daughter of the last Anglo-Saxon king Harald, who died in 1066. Information about this marriage has long been used in science, but, trying to determine its political significance historians were forced to limit themselves to general proposals. It seems that here, too, the new data on Svyatoslav's foreign policy bring enough clarity.

The generally accepted scientific dating of the marriage of Vladimir Monomakh and Gid $(1074 / 75)$ is determined and based solely on the date of birth of Monomakh's eldest son, Mstislav (February 1076). The Danish chronicle Saxon Grammar notes that the marriage was initiated by King Sven Estridsen of Denmark, who was the cousin of the Guides' father and remained in court after he was forced to leave England. A possible reason for Sven's actions is sometimes seen in the fact that her second marriage was allegedly married to Yaroslav the Wise's daughter Elizabeth, who was widowed in 1066 (her first husband, King Harald the Severe of Norway, died in the Battle of Stanford Bridge against Harald, the father of the guides) [14].

This error, which stems from old Scandinavian historiography, is due to a misinterpretation of the message of Adam von Bremen (1970s, 11th century). Kuchkin V.A. "Lessons" by Vladimir Monomakh and Russian-Polish-German relations of the 6os - 70s XI- V. // Soviet Slavic Studies. 1971. [2. 24-25], where in fact we are talking about the wedding of the Swedish king Hakon, and not about Elizaveta Yaroslavna, but about the "mother of Olaf the Younger", ie Norwegian king Olav Tikhy, who was not his son, but his stepson Elizabeth. Taking into account the role of Sven Estridsen in choosing a bride for Vsevolodov's son, one can only look at the close alliance between the Danish king and Henry IV in the 1970s [17].

They meet in Bardovik, near Luneburg, in 1071, and probably again in 1073; in the fall of 1073 , Sven even took military action against the Saxons in a war with Henry. Commentators are probably right that they doubt the validity of the opinions of Lampert of Gersfeld (inclined to see everything as anti-Saxon machinations of Henry IV), as if already in 1071 negotiations with Sven concerned joint actions against the Saxons.

Therefore, it would hardly be too bold to assume that, apart from the cases connected with the Hamburg Metropolitan, then a sudden conflict between Germany and Poland was discussed. The simultaneity of the GermanChernigov and German-Danish negotiations suggests that the initiative of the Danish king during the marriage of Vladimir Monomakh and the guides could be associated with these negotiations. Given the above, it seems to us that the marriage of Vsevolodovich with the English exiled princess should be viewed as a manifestation of the coordinated international policy of Svyatoslav and Vsevolod in 1069-1072, aimed at isolating Boleslav II, Izyaslav's main ally. Yaroslavich.

In this case, the marriage of Vladimir Monomakh was to be concluded between 1072 and 1074. Until now, there is no reason for Vsevolod to join the Danish-Chernigov coalition against Poland at a later time, starting from the turn of 1074-1075. The "Polish question" has lost its relevance for the younger Yaroslavich. It was at this time that their relations with Boleslav II were settled, which led not only to the scandalous expulsion of Izyaslav from Poland at the end of 1074 and peace between Poland and Russia after Easter in 1075, as well as a joint action against the Czech Republic with the participation of Oleg Svyatoslavich 
and Vladimir Monomakh in autumn - winter 1075/76 [21].

\section{CONCLUSION}

There is no doubt about the importance of political ties in the ancient Russian state. Kievan Rus was a very young state that had to consolidate its position on the stage of the political world in the ninth century.

Dynastic ties largely determined the political and economic course of the country. Each of the worthy rulers wanted to intermarry with another worthy ruler. This ensured stable trade and assistance in military raids against enemies.

The policy was unsustainable not only due to external factors but also due to internal problems. Culture and religion shook the state, and until there was general solidarity, these two factors hindered the development of Kievan Rus.

Political and dynastic relations played a positive role in the formation and development of the Russian state. I think that this important period for our country should be carefully studied, because not all historical events are clearly known.

\section{REFERENCES}

1. Artemov V. V. History of the Fatherland. From ancient times to the present day / V.V. Artemov, Yu.N. Lubchenkov. Moscow: Academia. 2020. -p. 360.

2. Bychkov S. P. History of Russia / Bychkov S. P; Yu.P. Dus. Moscow: Omsk State University, 2019. -p. 396.

3. Volkov V.A History of Russia from ancient times to the end of the 17th century. Textbook and workshop /
Volkov V.A. Moscow: Yurayt. 2016. -p. 452.

4. Grekov B. D. Struggle of Russia for the creation of its own state / B. D. Grekov. Moscow: Talking book. 2016. -p. 453.

5. Danilov A.A. History of Russia from ancient times to the present day in questions and answers / Danilov A.A. Moscow: Prospect. 2017. -p. 320.

6. Zemtsov B. History of Russia / Zemtsov B; Shubin A; Danilevsky I. Moscow: Peter. 2017. -p. 454.

7. Zemtsov B.N. History of Russia. IX early XXI century / Zemtsov B.N. Moscow: University book. 2018. -p. 552.

8. Zuev M.N. History of Russia. Textbook and workshop / Zuev M.N. S. Ya. Lavrenov. Moscow: Yurayt. 2016. -p. 638.

9. History of Russia IX - XX centuries. Textbook. Moscow: INFRA-M. 2020. p. 816.

10. History of Russia from ancient times to the beginning of the XXI century. Moscow: Bustard. 2016. -p. 656.

11. History of the USSR from ancient times to the end of the 18th century. Textbook. Moscow: Higher school. 2015. -p. 416.

12. Klyuchevsky V.O. Course of Russian history. Volume 5: monograph. / V.O. Klyuchevsky. Moscow: DirectMedia Publishing. 2017. -p. 959.

13. Kuvshinov. Patriotic History. Part 2 /; Kuvshinov. Moscow: IL. 2019. -p. 325.

14. Kuvshinov. Patriotic History. Part 4 /; Kuvshinov. Moscow: SINTEG. 2016. -p. 870.

15. The course of national history of the IX$\mathrm{XX}$ centuries. The main stages and features of the development of Russian society in the world historical 
process. Textbook. Moscow: ITRK. 2017. -p. 640.

16. Munchaev Sh. M. Political history of Russia / Munchaev Sh.M; Ustinov V.M. Moscow: Norma. 2019. -p. 736.

17. Nesterenko E. I. History of Russia / Nesterenko E.I; Petukhova N.E; Ya.A. Moscow: Infra-M. University textbook. 2018. -p. 304.

18. Pavlenko N. I. History of Russia from ancient times to 1861 / Pavlenko N. I; Andreev I.L; Fedorov V.A. Moscow: Yurayt. 2020. -p. 716.

19. Pavlenko N. I. History of Russia. 17001861 Textbook / Pavlenko N.I; Andreev I.L; Fedorov V.A. Moscow; Yurayt. 2016. -p. 310.

20. Fedorov V.A. History of Russia from ancient times to the present day. Textbook / Fedorov V.A. Moscow: KnoRus. 2016. -p. 724.

21. Fomin V. V. The initial history of Russia I Fomin V.V. Moscow: Russian panorama, 2018. -p. 296. 